\title{
Praktek Bunga Majemuk Rentenir dan Larangannya Dalam Perspektif Ekonomi Islam
}

\author{
Rachmad Risqy Kurniawan, SEI, MM \\ Sekolah Tinggi Ilmu Ushuluddin Darul Qur'an Mulia, Bogor \\ Email: rah.rizqy@gmail.com \\ Arina Maemanah \\ Sekolah Tinggi Ilmu Ushuluddin Darul Qur'an Mulia, Bogor \\ Email: Arina07apr@gmail.com
}

\begin{abstract}
The purpose of this study is to examine solutions to the problem of compound interest practice or interest-bearing practices carried out by moneylenders according to the interpretation of the Al-Quran Surah Ali Imran verse 130. This research is a library research with the maudu'i (thematic) interpretation method. and the method of interpretation of tahlili (analytic). The results of this study indicate that the practice of compound interest or interest-bearing practices carried out by loan sharks is not in accordance with the perspective of Islamic economics, Allah SWT expressly prohibits the practice of interest-bearing or multiplying in Surah Ali Imran verse 130. This study also provides solutions to the need for loans with nominal small, fast process and without collateral using a sharia-compliant kafalah contract through the Baitul Maal Wat Tamwil Sharia Financial Services Cooperative (KJKS BMT).
\end{abstract}

\section{Keywords: Compound Interest, Moneylenders, Kafalah, KJKS BMT}

Abstrak: Tujuan penelitian ini untuk mengkaji solusi-solusi atas masalah praktek bunga majemuk atau praktek bunga berbunga yang dilakukan oleh rentenir menurut tafsir Al-Quran Surat Ali Imran ayat 130. Penelitian ini merupakan penelitian kepustakaan (library research) dengan metode penafsiran maudu' $i$ (tematik) dan metode penafsiran tahlili (analitik). Hasil penelitian ini menunjukkan praktek bunga majemuk atau praktek bunga berbunga yang dilakukan oleh rentenir tidak sesuai dengan perspektif ekonomi Islam, Allah SWT secara tegas melarang praktek bunga berbunga atau bunga berlipat-lipat dalam Surat Ali Imran ayat 130. Penelitian ini juga memberikan solusi atas kebutuhan pinjaman dengan nominal kecil, dengan proses cepat dan mudah serta tanpa agunan yang sesuai syariah Islam melalui Koperasi Jasa Keuangan Syariah Baitul Maal Wat Tamwil (KJKS BMT).

Kata Kunci: Bunga Majemuk, Rentenir, Kafalah, KJKS BMT

\section{Pendahuluan}

Menurut data BPS, tingkat kemiskinan di Indonesia masih cukup tinggi, penduduk miskin pada September 2020 sebanyak 27,55 juta jiwa atau meningkat 2,76 juta dibandingkan tahun sebelumnya. Pada periode September 2020, tingkat kemiskinan menjadi 10,19 persen atau meningkat 0,97 poin persentase (pp) dari 9,22 
persen periode September 2019. ${ }^{1}$ Dengan kondisi perekonomian masyarakat bawah ini, memaksa sebagian masyarakat yang mayoritas pedagang kecil untuk meminjam hari ini sebagai modal usaha hari ini sekaligus juga untuk makan hari ini, kondisi kemampuan finansial harian melalui pinjaman/utang seperti inilah yang menjadi ladang praktek bunga berbunga yang dilakukan oleh rentenir marak di masyarakat. ${ }^{2}$

Merujuk pada Kamus Besar Bahasa Indonesia (KBBI), rentenir adalah orang yang mencari nafkah dengan membungakan uang. ${ }^{3}$ Dikutip dari laman Sikapi Uang Otoritas Jasa Keuangan (OJK), rentenir adalah orang yang meminjamkan uang kepada masyarakat dalam rangka memperoleh keuntungan melalui penarikan sejumlah bunga, ${ }^{4}$ bahkan dalam beberapa kasus dalam penagihannya disertai dengan kekerasan yang merupakan tindakan melawan hukum yaitu pasal 335 ayat 1 KUHP tentang perbuatan tak menyenangkan, ${ }^{5}$ meski demikian perilaku rentenir tidak bisa diperdatakan apalagi dipidanakan, karena dalam prakteknya kontrak pinjam meminjam dengan bunga itu sudah disepakati sehingga sah/legal menurut hukum, yang bisa dilakukan oleh masyarakat adalah memilih opsi-opsi yang lebih berkeadilan dan menentramkan sebagaimana yang ditawarkan oleh lembaga keuangan syariah.

Jika mengkaji masalah perekonomian Indonesia saat ini, maka kondisi perekonomian sangat dipengaruhi oleh adanya lembaga keuangan sebagai lembaga yang ikut andil dalam meningkatkan kegiatan perekonomian Indonesia, dengan kata lain lembaga keuangan merupakan salah satu agen pembangunan (agent of development) yang peran dan fungsinya sebagai wadah intermediasi keuangan untuk masyarakat Indonesia secara umum. Terlebih perekonomian di Indonesia dalam beberapa tahun terakhir masih terpuruk dan belum menunjukkan indikasi perbaikan secara kolektif pada semua aspek ekonomi akibat pandemi Covid-19, kondisi ini mengakibatkan meningkatnya angka kemiskinan sebagaimana dijelaskan diawal.

Sebagai salah satu negara yang memiliki jumlah penduduk yang cukup besar, bahkan pada September 2020 jumlah penduduk Indonesia sudah mencapai 270,20 juta jiwa $^{6}$ dan mayoritasnya beragama Islam, ajaran Islam telah melarang praktek bunga berbunga secara jelas dalam Q.S. Ali Imran ayat 130, maka diperlukan alternatif permodalan maupun pembiayaan yang sesuai syariah bagi masyarakat muslim agar terbebas dari jerat rentenir. Keberadaan lembaga keuangan syariah yang dapat menjangkau permodalan masyarakat kalangan bawah dengan persyaratan mudah, akses

1 Badan Pusat Statistik, Berita Resmi Statistik: Profil Kemiskinan di Indonesia September 2020, Jakarta:BPS, 2021).

2 Mochammad Faizun, Dede Nurohman, Syamsul Umam, "Pola Dan Formulasi Pembebasan Ketergantungan Pedagang Kecil Dari Rentenir:Studi Kasus di Pasar Ngemplak Tulungagung” AnNisbah: Jurnal Ekonomi Syariah Volume 07, Nomor 01, April 2020.

${ }^{3}$ Badan Pengembangan dan Pembinaan Bahasa Kementerian Pendidikan dan Kebudayaan Republik Indonesia, Kamus Besar Bahasa Indonesia Edisi Kelima, Jakarta: Balai Pustaka, 2017.

4 https://sikapiuangmu.ojk.go.id/FrontEnd/CMS/Article/20657 dan Ilas Korwadi Siboro, Rentenir (Analisis Terhadap Fungsi Pinjaman Berbunga Dalam Masyarakat Rokan Hilir Kecamatan Bagan Sinembah Desa Bagan Batu). Jom FISIP Volume 2 No. Oktober 2015.

${ }^{5}$ R. Soesilo, Kitab Undang-undang Hukum. Pidana (KUHP) serta Komentar-komentarnya Lengkap Pasal Demi Pasal, Politea, Bogor, 2013

${ }^{6}$ Badan Pusat Statistik, Berita Resmi Statistik Hasil Sensus Penduduk 2020, Jakarta: BPS, 2020 
yang cepat dan tanpa agunan, sangat diharapkan untuk menjadi solusi dari praktek bunga majemuk atau bunga berbunga yang semakin mencekik kehidupan mereka.

Berlandaskan permasalahan diatas, peneliti ingin mengkaji lebih dalam solusisolusi atas masalah praktek bunga majemuk atau praktek bunga berbunga yang dilakukan oleh rentenir menurut tafsir Al-Quran Surat Ali Imran ayat 130. Penelitian ini merupakan penelitian kepustakaan (library research) dengan menggunakan literatur (kepustakaan) sebagai sumber antara lain kitab tafsir dan artikel ilmiah pendukung lainnya, metode penafsiran yang digunakan dalam penelitian ini adalah metode penelitian maudu'i (tematik) dan metode penafsiran tahlili (analitik). Penafsiran maudu' $\mathrm{i}$ (tematik) adalah penulisan karya tafsir yang struktur pemaparannya mengacu pada tema tertentu atau pada ayat, surat atau juz tertentu yang ditentukan oleh penafsir sendiri. Sedangkan metode penafsiran tahlili (analitik) adalah metode menafsirkan AlQuran yang berusaha menjelaskan Al-Quran dengan menguraikan berbagai seginya dan menjelaskan apa yang dimaksudkan oleh Al-Quran.

\section{Praktek Bunga Majemuk Rentenir dan Dalil Pelarangannya}

Pengertian riba secara etimologi berasal dari bahasa arab yaitu dari kata ribayarbu-rabwan yang berarti az-ziyadah (tambahan) atau al-fadl (kelebihan). Sebagaimana yang disampaikan dalam al-Qur'an: yaitu pertumbuhan, peningkatan, bertambah, meningkat, dan menjadi besar. Pengertian riba secara umum berarti meningkat, baik itu menyangkut kualitas maupun kuantitasnya. Sedangkan menurut istilah, riba adalah mengambil tambahan dari harta pokok atau modal secara batil. Dalam kaitannya dengan pengertian al batil, Ibnu Al- Arabi Al Maliki dalam kitabnya Ahkam Al-Quran menjelaskan pengertian riba secara bahasa adalah tambahan, namun yang di maksud riba dalam ayat qur'ani, yaitu setiap penambahan yang di ambil tanpa adanya transaksi pengganti atau penyeimbang yang dibenarkan syariah ${ }^{7}$.

Jadi dapat disimpulkan bahwa riba adalah memakan harta orang lain tanpa adanya jerih payah dan mendapatkan harta bukan sebagai imbalan kerja atau jasa, melainkan mengambil harta orang lain dengan cara yang batil, serta mengabaikan aspek prikemanusiaan demi menghasilkan keuntungan materi pribadi. Meski demikian, praktek riba marak terjadi di masyarakat sebagai contoh keberadaan rentenir, bank keliling dan bank konvensional, yang memberikan tawaran-tawaran permodalan dengan tambahan bunga yang merupakan praktek riba, bahkan seringkali bunga yang diambil merupakan bunga majemuk atau bunga berbunga. ${ }^{8}$

Dalam masyarakat Indonesia praktik meminjam uang pada rentenir dan Bank Konvensional merupakan satu-satunya jalan alternatif. Terlebih pada kondisi yang sungguh menyedihkan dengan adanya wabah pandemi Covid-19. Padahal Allah SWT telah melarang dengan tegas praktek riba ini dengan firman-Nya Q.S Ali Imron ayat 130:

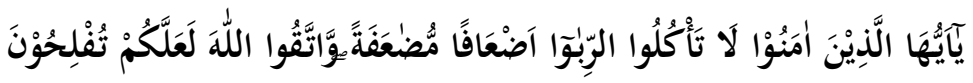

${ }^{7}$ Ibnu Al-Arabi, Ahkam al-Quran, juz 1, Mesir: Isa al-Halaby, 1957, hlm. 321 dalam Abdul Ghofur, Konsep Riba Dalam Al-Qur'an, Jurnal Economica Volume VII/Edisi 1/Mei 2016

${ }^{8}$ Devie, Tinjauan Atas Suku Bunga Dan Dampaknya Pada Keputusan Investasi Dan Pembiayaan, Jurnal Akuntansi \& Keuangan Vol. 2, No. 2, Nopember 2000: 162 - 173

Ulumul Qur'an: Jurnal Ilmu Al-Qur'an dan Tafsir

Volume x, Nomor x, September 20xx | p-ISSN: 0000-0000; e-ISSN: 0000-000| xx-xx 
Artinya: Hai orang-orang yang beriman, janganlah kalian memakan riba dengan berlipat ganda dan bertakwalah kalian kepada Allah supaya kalian mendapat

$$
\text { keberuntungan"9. }
$$

Ayat diatas menjelaskan tentang hukum riba menurut syariat Islam. Setiap pemanfaatan riba ataupun penggunaan riba yang berlipat-lipat dilarang dalam Islam dan hukumnya haram. Mujahid mengatakan, "Orang-orang Arab sering mengadakan transaksi jual beli tidak tunai. Jika jatuh tempo sudah tiba dan pihak yang berhutang belum mampu melunasi maka nanti ada penundaan waktu pembayaran dengan kompensasi jumlah uang yang harus dibayarkan juga menjadi bertambah.",10

Praktek riba bahkan sudah dilakukan oleh kaum yahudi sejak dahulu sehingga Allah SWT telah melarangnya namun mereka tidak mau menaati apa yang Allah larang sebagaimana dalam QS. An-Nisa' Ayat 161:

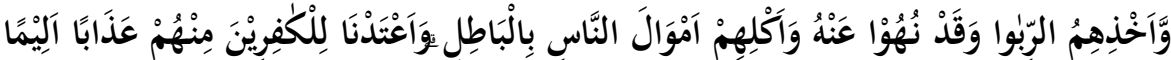

Artinya: Dan karena mereka menjalankan riba, padahal sungguh mereka telah dilarang darinya, dan karena mereka memakan harta orang dengan cara tidak sah (batil). Dan Kami sediakan untuk orang-orang kafir di antara mereka azab yang pedih.

Menurut tafsir At-Thabari dari Ibnu Humaid dari Salamah dan Ibnu Ishaq: Makna ayat يا أيها الذين آمنوا لا تأكلوا الربا أضعافًا مضاعفة adalah jangan kalian memakan harta orang lain dengan memberi utang lalu mengambil bunga berlipat lipat darinya, karena apa yang dimakan itu tidak halal hukumnya dan telah dilarang oleh Allah SWT. ${ }^{11}$

Imam Ibnu Jarir at-Thabari juga mendasarkan penafsirannya pada riwayat yang dinukil dari Muhammad bin Amru, dari Ashim, dari Isa, dari Ibnu Abi Najih, dari Mujahid, beliau berkata bahwa yang dimaksud dengan riba yang disinggung dalam ayat يا أيها الذين آمنوا لا تأكلوا الربا أضعافًا مضاعفة, adalah riba jahiliyah.

Adapun maksud dari "riba jahiliyah" di sini, sebagaimana dijelaskan oleh Al Thabary dengan mendasarkan penyandaran riwayat pada Yunus, dari Ibnu Wahbin, Ibnu Zaid, disampaikan bahwa maksud dari ayat: لا تأكلوا الربا أضعافًا مضاعفة, adalah

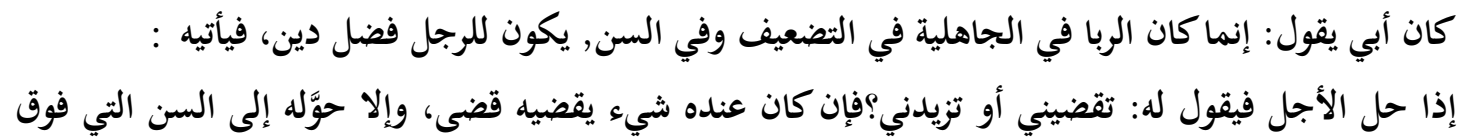

\footnotetext{
${ }^{9}$ Q.S Ali Imron : 130

${ }^{10}$ Al- Qurtubi, Ahmad Muhammad bin. Al-Jāmi' Li Ahkām Al-Qur'an. Bairut-Libnan: Muassasah alRisālah, 2006 dalam Ahmad Naufal, Riba Dalam Al-Quran Dan Strategi Menghadapinya, Al Maal: Journal of Islamic Economics and Banking, Vol 1 No 1 Bulan Juli Tahun 2019, Hal. 100 - 116

${ }^{11}$ Al-Ṭhabarī , Abu Ja"far Muḥammad Ibn Jarīr Ibn Yazīd Ibn Kathir Ibn Gālib . Jāmi'u al-Bayān fì Ta 'wīli al-Qur 'ān (Beirut: Daarul Kitab, 1412 H/1992 M)
} 


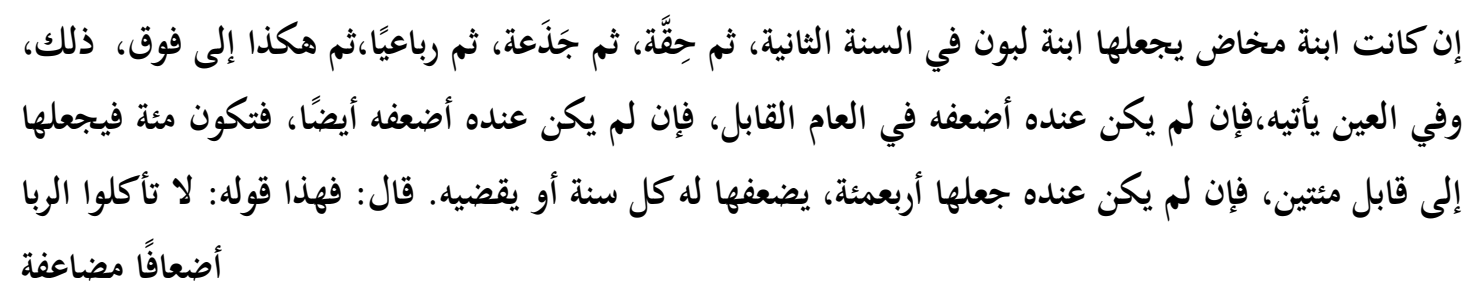

Artinya: "Adalah bapakku berkata: "Sesungguhnya riba di masa jahiliyah adalah dilaksanakan dengan basis تضعيف (melipatgandakan) dan السن (tahun/masa), yaitu: kelebihan utang oleh seorang laki-laki yang diterima saat jatuh tempo pembayaran. Ia berkata kepada orang yang diutangi: “تقنضيني أو تزيدني" (Kamu lunasi sekarang, atau kamu berikan tambahan kepadaku?". Jika ia sanggup melunasi, maka dilunasi. Namun, bila dilakukan pengubahan tempo pelunasan dengan menambah "tahun pelunasan" berupa tahun berikutnya, maka bila utangnya berupa unta bintu makhadz, maka ia harus mengembalikan utang berupa bintulabûn di tahun ke dua. Bila utang berupa unta hiqqah, maka dikembalikan berupa jadz'ah, kemudian dikalikan empat, demikian seterusnya, semakin bertambah tahun, semakin bertambah kelipatannya. Dan bila utang itu berupa 'ain (barang), jika ia tidak melunasinya di tahun jatuh tempo itu, maka diambil kelipatannya di tahun mendatang. Dan bila ditahun berikutnya, masih juga belum dilunasi, maka dilipatkannya lagi. Jika semula utangnya sebesar 100, maka berubah menjadi 200 di tahun berikutnya (2 kali lipat). Dan di tahun berikutnya, bila belum dibayar lagi, maka berubah menjadi 400. Demikianlah, berubah هذا " مون (inilah maksud dari ayat jangan memakan riba dengan melipatgandakan lagi dilipatgandakan). ${ }^{12}$,

As'sa'di menafsirkan ayat ini sebagai peringatan tentang beratnya kekejian karena banyaknya akibat berlipat lipat berbunga bunga, dan peringatan tentang hikmah larangannya, dan bahwa hikmah dari larangan riba adalah Allah mencegah kezaliman yang dikandungnya. Karenanya Allah SWT memerintahkan untuk memperhatikan orang-orang yang tidak mampu, dan agar dia berhutang tanpa tambahan, sehingga jika melanggara dua-duanya yaitu tidak memperhatikan orang yang tidak mampu sekagus memberatkan mereka dengan tambahan atas utangnya maka ini merupakan kezaliman ganda, maka orang mukmin yang solih imannya harus meninggalkannya dan tidak mendekatinya, karena menghindari praktik riba ini adalah bagian dari ketakwaan dan kesejahteraan itu bergantung pada ketakwaan manusia. ${ }^{13}$

Al-Baghwy menafsirkan bahwa riba berlipat ganda ini merupakan jalan yang salah dalam memperbanyak uang dengan menunda pembayaran, ${ }^{14}$ padahal Allah SWT

\footnotetext{
${ }^{12}$ Al-Ṭhabarī, Abu Ja"far Muḥammad Ibn Jarīr Ibn Yazīd Ibn Kathir Ibn Gālib . Jāmi’u al-Bayān fì Ta 'wìli al-Qur 'ān (Beirut: Daarul Kitab, 1412 H/1992 M) Juz 7, hlm 204. Demikian juga, diriwayatkan oleh al-Bayhaqi dalam Sunan-nya (10773) dan al-Ma rifa (3396) fathul Al-Bari” (4/313). Tafsir Ibn Abi Hatim (3/759).

${ }^{13}$ Syaikh Abdurrahman bin Nashir as-Sa'di . Taisirul Karimirrahman fi Tafsiri Kalamil Mannan. Cet. I; Baerut: Dar Ibn Hazm, 2003.

${ }^{14}$ Al-Baghawiy, Al-Husain bin Masúd. Ma'alim al-Tanzil,. Jilid. 1. Riyad: Dar al-Taybah, 1409.
} 
memerintahkan untuk memberi tenggang waktu bahkan memerintahkan untuk menyedekahkan saja, Firman Allah SWT QS. Al-Baqarah Ayat 280

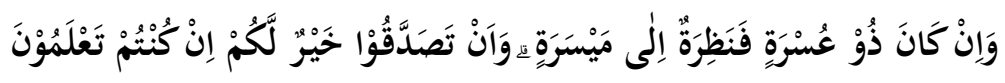

Artinya: Dan jika (orang berutang itu) dalam kesulitan, maka berilah

tenggang waktu sampai dia memperoleh kelapangan. Dan jika kamu menyedekahkan,

itu lebih baik bagimu, jika kamu mengetahui.

Menurut tafsir ibnu katsir, Allah SWT telah melarang hamba-hamba-Nya yang beriman untuk terlibat dalam riba dan mengkonsumsinya secara eksponensial, seperti yang biasa mereka katakan di era pra-Islam - jika jangka waktu utang itu datang: apakah dia membayarnya atau dia meningkatkannya, maka dia membayarnya. itu, jika tidak, dia meningkatkannya dalam periode dan meningkatkannya jumlah yang harus dibayar, dan ini berlaku setiap akhir tempo, yang tadinya sedikit dapat dikalikan hingga menjadi berkali kali lipat banyaknya. Inilah yang Allah SWT larang bagi orang-orang yang beriman dan bertakwa agar mendapatkan keberuntungan. ${ }^{15}$

Imam al- Qurthuby dari Mujahid berkata: Mereka biasa menjual penjualan untuk jangka waktu tertentu, dan ketika datang waktu, mereka menaikkan harga dengan syarat ditunda. Kemudian Allah SWT berfirman: Hai orang-orang yang beriman, janganlah kamu memakan riba yang berlipat ganda dan berlipat ganda. Karena itu adalah yang di dalamnya Allah mengizinkan perang dalam firman-Nya: Jika kamu tidak melakukannya, maka izinkan perang dari Allah dan Rasul-Nya, dan perang diizinkan untuk membunuh; Seolah-olah Allah berkata: Jika kamu tidak takut riba, kamu akan dikalahkan dan dibunuh. Jadi Allah memerintahkan mereka untuk meninggalkan riba; Karena itu sudah menjadi kebiasaaan orang-orang jahiliyah sejak zaman dahulu mengggandakan hartanya dengan menunda pembayaran utang piutang berharap uangnya berlipat ganda berkali kali lipat dengan bunganya dan Allah maha tahu yang terbaik bagi manusia. ${ }^{\mathbf{1 6}}$

Dari riwayat di atas maka dapat disimpulkan bahwa Allah SWT melarang keras terhadap tranksaksi riba yakni melipatgandakan dan dilipatkan. Hal ini sama saja dengan mengambil keuntungan yang merupakan hak orang lain secara paksa dengan mengadakan perjanjian yang harus dipenuhi si peminjam. Pada masa sekarang, riba ini disebut dengan riba fahisy (keterlaluan labanya) atau riba yang labanya berlipat ganda dari modalnya. Seperti yang dilakukan oleh lembaga bank konvesional dan rentenir. Padahal Allah SWT dengan tegas telah melarang dalam surah Ali Imran ayat 130. Kemudian memberikan peringatan kepada orang yang tidak mau meninggalkannya, bahwa mereka diperangi oleh Allah dan Rasul-Nya. Bahkan ancaman seperti ini belum pernah ada dalam dosa besar lainnya, oleh karenanya riba dikategorikan dosa besar yang terbesar. Hal ini diperkuat oleh sabda Rasulullah yaitu :

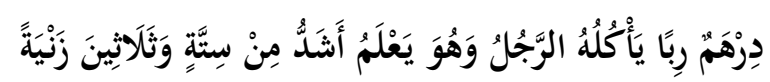

\footnotetext{
${ }^{15}$ Ibnu Katsir, Tafsir al-Qur'an al-Adzim (Beirut : Daar al-Fikr, 1923)

${ }^{16}$ Al-Qurtubi, Ahmad Muhammad bin. Al-Jāmi' Li Ahkām Al-Qur'an. Bairut-Libnan: Muassasah alRisālah, 2006.
} 
Artinya: Satu dirham uang riba yang dimakan oleh seseorang dalam keadaan mengetahui bahwa itu adalah uang riba dosanya lebih besar dari pada berzina

$$
\text { sebanyak } 36 \text { kali. }^{17},
$$

Bukankah begitu kejinya perbuatan ini sehingga dalam hadits lain pun disebutkan bahwa orang yang mengambil riba itu tidak diterima sedekahnya, jihadnya, hajinya, dan shalatnya. ${ }^{\mathbf{1 8}}$

$$
\text { وَاتقَّوا الَّلَهَ لَعَلَّكُمْ ثُفْلِحُونَ }
$$

"Bertakwalah kalian kepada Allah dalam hal-hal yang dilarang" diantaranya ialah riba, dan janganlah kalian berlaku kasar dan keras hati terhadap sesama. Sesungguhnya kita diciptakan untuk saling tolong menolong dalam hal apapun. karena harta hanyalah titipin yang bisa hilang kapan saja. Janganlah kalian memeras mereka dengan membebankan hutang yang tak sanggup mereka tanggung. Niscaya Allah akan memuliakan dan mengangkat derajat hambanya yang memudahkan urusan hamba yang lain.

\section{Solusi Ekonomi Islam Terhadap Praktik Rentenir}

Dalam konsep Islam di tegaskan bahwa masalah ekonomi dapat dilakukan oleh siapa saja dan kapan saja, namun harus sesuai dengan tuntunan ajaran Alquran dan Sunnah. Salah satu konsep yang ditanamkan Alquran kepada manusia agar dalam praktik pelaksanaan ekonomi menghindari riba karena mengambil harta orang lain dengan cara yang batil. Batil dalam hal ini adalah perbuatan ketidakadilan dan akan menimbulkan kezaliman di antara para pelaku ekonomi.

Tidak dapat dipungkiri bahwa mayoritas masyarakat muslim di Indonesia masih belum mampu menerapkan prinsip ekonomi islam itu sendiri. Hal ini dapat dilihat dari banyaknya tranksaksi melalui bank konvesional. Dimana tranksaksi yang di anut oleh sistem ini tidak sesuai dengan ajaran islam karena adanya tambahan pembayaran atau sering di sebut dengan sistem bunga Bank. Hal ini tentu saja tidak sesuai dengan ajaran Islam karena menguntungkan salah satu pihak dan merugikan pihak yang lain. Dengan tidak adanya penegasan atau tindakan dari semua pihak dalam hal ini maka timbul masalah yaitu permusuhan antar sesama, kurangnya rasa peduli dan munculnya egoisme.

Dalam sejarah islam, lembaga Baitul Maal, sejak zaman Rasulullah SAW berfungsi untuk mengurusi keuangan negara sehingga Rasulullah SAW adalah kepala baitul mal pertama yang memperkenalkan konsep pada bidang keuangan negara yaitu dengan mengumpulkan uang negara pada lembaga ini dan menyalurkan dana sesuai dengan kebutuhan negara. Hasil pengumpulan ini milik negara bukan milik individu.

\footnotetext{
${ }^{17}$ HR. Ahmad dari Abdulloh bin Hanzholah dan dinilai shahih oleh Al Albani dalam Shahih al Jami', no. 3375 Dalam Fedra Hermawan, Praktek Hutang Uang Di Bayar Beras Di Desa Durian Sebatang Kecamatan Kedurang Kabupaten Bengkulu Selatan Perspektif Ekonomi Islam Skripsi Program Studi Ekonomi Syariah Fakultas Ekonomi Dan Bisnis Islam Institut Agama Islam Negeri (IAIN) Bengkulu Bengkulu, 2020

${ }^{18}$ Al- Maraghi, Ahmad Mushthafa, Tafsir Al Maraghi Jilid 6, Diterjemahkan oleh Abubakar B, Aly H N, dan Sitanggal A U, Diedit oleh Rasyid A dan Dasuki H, Semarang: Toha Putra Semarang, Cetakan Pertama. 1987 Hal. 30-35 dalam Salman Al Parisi, Iwan Hermawan, Marta Kurniawan, Ibnu Saud Habibullah, Perspektif Riba dan Studi Kontemporer-Nya dengan Pendekatan Tafsir Al Quran dan Hadits Jurnal Ekonomi Syariah Indonesia, Volume VIII, No. 1 Juni 2018 Hal. 23-36
} 
Di Indonesia sendiri istilah BMT terdengar pada awal 1992 yang dimana istilah ini muncul dari prakarsa sekelompok aktivis yang kemudian mendirikan BMT Bina Insan Kamil di Jalan Pramuka Sari II Jakarta. Banyak hal yang mendorong lahirnya BMT salah satunya akan timbulnya pengikisan akidah dipengaruhi oleh lemahnya ekonomi masyarakat. Maka keberadaan BMT diharapkan mampu mengatasi masalah ini lewat pemenuhan kebutuhan-kebutuhan ekonomi masyarakat. ${ }^{19}$

Baitul Mal Wat Tamwil (BMT) yang mengacu pada aturan hukum koperasi yang sesuai syariah berfungsi menghimpun dan menyalurkan dana kepada masyarakat menengah ke bawah. BMT ini merupakan balai usaha mandiri yang mempunyai kegiatan untuk mengembangkan usaha-usaha produktif dan investasi dalam meningkatkan ekonomi kalangan bawah khususnya terkait permodalan usaha-usaha kecil. Selain itu BMT juga menerima titipan zakat, infaq, shadaqoh dan wakaf dan menyalurkannya sesuai dengan peraturan dalam Islam.

Secara kelembagaan, badan hukum BMT dapat berbentuk koperasi, yayasan, perseroan terbatas (PT) ${ }^{\mathbf{2 0}}$ Konsep BMT berdasarkan prinsip koperasi semula mengacu pada Undang-Undang Nomor 25 Tahun 1992 tentang Perkoperasian (UU Perkoperasian) namun UU tersebut sudah dicabut dan diganti dengan Undang-Undang Republik Indonesia Nomor 17 Tahun 2012 Tentang Perkoperasian, bentuk BMT koperasi ini mempunyai keistimewaan karena asas, tujuan, nilai dan prinsipnya sesuai dengan prinsip syariah salah satunya untuk memenuhi kebutuhan di bidang ekonomi.

Sifat saling tolong menolong diantara anggota koperasi juga diperluas dalam UU ini dengan memungkinkan penyediaan pinjaman bukan hanya kepada anggotanya saja namun untuk semua masyarakat. Karena koperasi merupakan badan usaha swadaya yang otonom, dan independen sehingga memungkinkan untuk membuat berbagai alternatif model pembiayaan yang tepat guna untuk menghentikan praktik rentenir salah satunya dapat berupa pinjaman ringan, mudah, cepat serta tanpa agunan karena hal itu dimungkinkan menurut Pasal 27 Bagian Ketujuh Jaminan Peraturan Menteri Koperasi Dan Usaha Kecil Dan Menengah Republik Indonesia Nomor 11/Per/M.KUKM/XII/2017 Tentang Pelaksanaan Kegiatan Usaha Simpan Pinjam Dan Pembiayaan Syariah Oleh Koperasi.

Opsi yang dapat digunakan untuk menjamin usaha koperasi adalah sistem tanggung renteng diantara anggota sehingga model usahanya dapat dengan mudah menjangkau masyarakat yang memang tidak ada agunan yang bisa dijaminkan serta memerlukan pinjaman dengan nominal kecil serta proses administrasi yang cepat. Selain itu fungsi pembinaan dan pengawasan aktif dari pengurus BMT dapat memacu pertumbuhan UMKM. Apalagi dengan fungsi maal yaitu fungsi sosial dari BMT untuk menghimpun zakat infaq dan sedekah dapat disalurkan sebagai bentuk zakat produktif bagi pedagang kecil sehingga tanpa bunga atau tambahan biaya adminitrasi atau biayabiaya lainnya. Sehingga prosesnya juga menjadi jauh lebih cepat dan mudah tanpa agunan karena memang bagian dari penyaluran zakat yang hanya membutuhkan syarat penerima yaitu mustahik zakat, dan pedagang kecil ini masuk kedalam golongan

\footnotetext{
${ }^{19}$ Heri Sudarsono, Bank dan Lembaga Keuangan Syariah Deskripsi dan Ilustrasi (Yogyakarta: Penerbit Ekonosia, 2004.) Hlm 97.

${ }^{20} 1$ Pasal 5 ayat (1) Undang-Undang Nomor 1 Tahun 2013 Tentang Lembaga Keuangan Mikro, Jakarta: DPR RI, 2013 dalam Tita Novitasari, Peran Otoritas Jasa Keuangan dalam Pengawasan Lembaga Baitul Maal wa Tamwil (BMT): Studi Kasus BMT Global Insani, Undang: Jurnal Hukum, Vol. 2 No. 1 (2019) Hal: 119-145
} 
mustahik miskin, selain itu keistimewaan lainnya juga dapat berbentuk penghapusan kewajiban bayar jika mereka mengalami kesusahan bayar sehingga masuk menjadi mustahik zakat kategori ghaarimin ${ }^{21}$

\section{Kesimpulan}

Berdasarkan hasil penelitian diatas, maka praktek bunga majemuk atau praktek bunga berbunga yang dilakukan oleh rentenir tidak sesuai dengan perspektif ekonomi Islam, Allah SWT secara tegas melarang praktek bunga berbunga atau bunga berlipatlipat dalam Surat Ali Imran ayat 130. Penelitian ini juga memberikan solusi atas kebutuhan pinjaman dengan nominal kecil, dengan proses cepat dan mudah serta tanpa agunan yang sesuai syariah Islam melalui Koperasi Jasa Keuangan Syariah Baitul Maal Wat Tamwil (KJKS BMT).

KJKS BMT merupakan sebuah jawaban bagi keresahan yang dirasakan masyarakat terutama di kalangan menengah ke bawah akibat praktik riba yang dilakukan rentenir, KJKS BMT memiliki peran penting bagi pertumbuhan perekonomian masyarakat secara luas. Hal ini dikarenakan BMT memberikan peluang bagi masyarakat dalam hal menghimpun simpanan dan menyalurkan dalam bentuk pinjaman. KJKS BMT dapat menjadi salah satu alternatif untuk meningkatkan taraf hidup perkenomian yang masyarakat, dengan memberikan pembiayaan untuk menambah modal usaha, sehingga usaha kecil mampu mengelola dan meningkatkan produktivitasnya. Dengan demikian masyarakat kecil tidak lagi meminjam kepada renternir yang tidak akan menyelesaikan masalah tapi justru menambah masalah yang mencekik masyarakat kecil karena memberi pinjaman dengan bunga yang tinggi serta terhindar dari praktik riba yang sangat dilarang oleh Allah SWT.

\section{Daftar Pustaka}

Abdul Ghofur, Konsep Riba Dalam Al-Qur'an, Jurnal Economica Volume VII/Edisi 1/Mei 2016

Ahmad Naufal, Riba Dalam Al-Quran Dan Strategi Menghadapinya, Al Maal: Journal of Islamic Economics and Banking, Vol 1 No 1 Bulan Juli Tahun 2019, Hal. $100-116$

Al- Maraghi, Ahmad Mushthafa, Tafsir Al Maraghi Jilid 6, Diterjemahkan oleh Abubakar B, Aly H N, dan Sitanggal A U, Diedit oleh Rasyid A dan Dasuki H, Semarang: Toha Putra Semarang, Cetakan Pertama. 1987 Hal. 30-35

Al Parisi, Salman,. Hermawan, Iwan,. Kurniawan, Marta,. Habibullah, Ibnu Saud,. Perspektif Riba dan Studi Kontemporer-Nya dengan Pendekatan Tafsir Al Quran dan Hadits, Jurnal Ekonomi Syariah Indonesia, Volume VIII, No. 1 Juni 2018 Hal. 23-36

Al- Qurtubi, Ahmad Muhammad bin. Al-Jāmi' Li Ahkām Al-Qur'an. BairutLibnan: Muassasah al-Risālah, 2006

Al-Baghawiy, Al-Husain bin Masúd. Ma'alim al-Tanzil,. Jilid. 1. Riyad: Dar al-Taybah, 1409.

\footnotetext{
${ }^{21}$ Haikal, Strategi Pendayagunaan Dana Baitul Maal Dalam Menanggulangi Pembiayaan Bermasalah Nasabah Gharimin (Studi Pada BMT Husnayain-Pasar Rebo Jakarta Timur) Skripsi Jakarta: Fakultas Syariah dan Hukum UIN Syarif Hidayatullah, 2013
} 
Al-Ṭhabarī, Abu Ja far Muḥammad Ibn Jarīr Ibn Yazīd Ibn Kathir Ibn Gālib . Jāmi’u al-Bayān fì Ta 'wōli al-Qur'ān (Beirut: Daarul Kitab, 1412 H/1992 M)

As-Sa'di, Syaikh Abdurrahman bin Nashir. Taisirul Karimirrahman fi Tafsiri Kalamil Mannan. Cet. I; Baerut: Dar Ibn Hazm, 2003.

Badan Pengembangan dan Pembinaan Bahasa Kementerian Pendidikan dan Kebudayaan Republik Indonesia, Kamus Besar Bahasa Indonesia Edisi Kelima, Jakarta: Balai Pustaka, 2017.

Badan Pusat Statistik, Berita Resmi Statistik Hasil Sensus Penduduk 2020, Jakarta: BPS, 2020

Badan Pusat Statistik, Berita Resmi Statistik: Profil Kemiskinan di Indonesia September 2020, Jakarta:BPS, 2021.

Devie, Tinjauan Atas Suku Bunga Dan Dampaknya Pada Keputusan Investasi Dan Pembiayaan, Jurnal Akuntansi \& Keuangan Vol. 2, No. 2, Nopember 2000: 162 173

DPR RI, Undang-Undang Nomor 1 Tahun 2013 Tentang Lembaga Keuangan Mikro, Jakarta: DPR RI, 2013

Faizun, Mochammad., Nurohman, Dede., Umam, Syamsul. "Pola Dan Formulasi Pembebasan Ketergantungan Pedagang Kecil Dari Rentenir:Studi Kasus di Pasar Ngemplak Tulungagung" An-Nisbah: Jurnal Ekonomi Syariah Volume 07, Nomor 01, April 2020.

Haikal, Strategi Pendayagunaan Dana Baitul Maal Dalam Menanggulangi Pembiayaan Bermasalah Nasabah Gharimin (Studi Pada BMT Husnayain-Pasar Rebo Jakarta Timur) Skripsi Jakarta: Fakultas Syariah dan Hukum UIN Syarif Hidayatullah, 2013

Hermawan, Fedra, Praktek Hutang Uang Di Bayar Beras Di Desa Durian Sebatang Kecamatan Kedurang Kabupaten Bengkulu Selatan Perspektif Ekonomi Islam Skripsi Program Studi Ekonomi Syariah Fakultas Ekonomi Dan Bisnis Islam Institut Agama Islam Negeri (IAIN) Bengkulu Bengkulu, 2020

Ibnu Al-Arabi, Ahkam al-Quran, juz 1, Mesir: Isa al-Halaby, 1957, hlm. 321

Ibnu Katsir, Tafsir al-Qur'an al-Adzim (Beirut : Daar al-Fikr, 1923)

Novitasari, Tita., Peran Otoritas Jasa Keuangan dalam Pengawasan Lembaga Baitul Maal wa Tamwil (BMT): Studi Kasus BMT Global Insani, Undang: Jurnal Hukum, Vol. 2 No. 1 (2019) Hal: 119-145

OJK, Terlanjur Meminjam Kepada Rentenir? Ini Dia Hal-Hal Yang Dapat $\begin{array}{lllll}\text { Kamu Lakukan! Accesed } & 2021\end{array}$ https://sikapiuangmu.ojk.go.id/FrontEnd/CMS/Article/20657

R. Soesilo, Kitab Undang-undang Hukum. Pidana (KUHP) serta Komentarkomentarnya Lengkap Pasal Demi Pasal, Bogor: Politea, 2013

Siboro, Ilas Korwadi Rentenir (Analisis Terhadap Fungsi Pinjaman Berbunga Dalam Masyarakat Rokan Hilir Kecamatan Bagan Sinembah Desa Bagan Batu). Jom FISIP Volume 2 No. Oktober 2015. 
Sudarsono, Heri, Bank dan Lembaga Keuangan Syariah Deskripsi dan Ilustrasi (Yogyakarta: Penerbit Ekonosia, 2004.) Hlm 97. 